\title{
Anti-obesity effect of the jasminum sambac (1.) W.ait. Ethanol extract in high fat diet induced mice
}

Muhammad Ramadhan ${ }^{1} *$

${ }^{1}$ Sari Mulia School of Health Sciences, Banjarmasin Indonesia

*rama.dhan836@stikessarimulia.ac.id

Ari Yuniarto ${ }^{2}$

${ }^{2}$ School of Pharmacy Bandung

ari_yuniarto@gmail.com

Ika Kurnia $S^{2}$.

${ }^{2}$ School of Pharmacy Bandung

ika_kurnia_s@gmail.com

\begin{abstract}
Objective:. The aim of this research is to identify the potential anti-obesity effect of Jasminum sambac (L.) W.Ait. ethanol extract in high-fat-diet-induced mice.

Method: This assay was administered to high-fat diet induced mice for 30 days, to get an increase of body weight of $20 \%$ higher than early body weight. After induction, obese mice groups were treated using Jasminum sambac (L.) W.Ait. ethanol extract at the dose 100, 300, $500 \mathrm{mg} / \mathrm{kg} \mathrm{BW}$ and orlistat $23 \mathrm{mg} / \mathrm{kg} \mathrm{BW}$ as standard drug. To determine the anti-obesity effect, measurements were conducted by daily weight, food index, feces index, urine index, and stool consistency. The data were statistically analyzed by One-Way ANOVA followed by LSD test (Least Significant Different).

Results: The experiment showed that Jasminum sambac (L.) W.Ait. extract dose of 100, 300, 500 $\mathrm{mg} / \mathrm{kg} \mathrm{BW}$ induced a high-fat diet indicated a significant decrease in body weight, fat index and organs index compared to control mice.

Conclusion: The best dose decrease in body weight in the dose of $100 \mathrm{mg} / \mathrm{kg} \mathrm{BW}$ and the best dose of reduced fat and organ weight in the dose of $300 \mathrm{mg} / \mathrm{kg} \mathrm{BW}$.
\end{abstract}

Keywords: Ethanol extract, High-fat diet, Jasminum sambac, Obesity

\section{INTRODUCTION}

According to the World Health Organization (WHO), obesity is one of the 10 factors that are most at risk of disease worldwide. The prevalence of obesity in the whole world both in developed countries and the developing countries has increased significantly [7]. According to the data from the Health Research in 2007 in Indonesia, the prevalence of obesity in the general population over the age of 15 years was $10.3 \%$ (men $13.9 \%$, women $23.8 \%$ ). While the prevalence of overweight children aged 614 years in males $9.5 \%$ and females $6.4 \%$ [4].

Obesity is an excessive accumulation of fat in the body. Another definition of obesity is the result of excessive calorie intake than the calories needed by the body [16]. These excess calories are caused by psychological disorders, metabolic and central nervous 
disorders associated with food intake regulation and lack of physical activity [6]. Overweight based WHO calculated the value of Body Mass Index (BMI) calculated the range of 25 to 29.99 and obesity with BMI $\geq 30[14]$.

Prevention of obesity is needed to prevent the onset of other diseases and improve quality of life. Obesity is associated with the risk of other diseases such as hyperlipidemia, hypertension, coronary heart disease, diabetes, cancer, gallbladder disease, back pain and even psychological problems. Non-pharmacological therapy can be done with diet and exercise, whereas pharmacological therapy is the use of synthetic drugs. Anti-obesity drugs or have a slimming effect restrain appetite, trigger fat burning and inhibits the absorption of fat within certain limits. Some slimming drugs or prevention of obesity in the market can cause adverse effects to health if consumed in the long term. So much more people choose the alternative therapy of medicinal plants because it is safer, fewer side effects [5].

White jasmine (Jasminum sambac) empirically used as anti-inflammatory, diaphoretic, diuretics, and launched respiratory [3]. Jasminum sambac is also used as an antibacterial [13], antioxidants [8]. A study of Jasminum sambac conducted by Kunhachan et al. showed that the ethanol extract of white jasmine flower has endothelium-dependent relaxation activity by stimulating the release of nitric oxide from the endothelium of blood vessels through muscarinic receptors, and the methanol extract showed white jasmine flowers and cytotoxic anticancer effects [9]. From research conducted by Lestari that white jasmine (Jasminum sambac (L.) W.Ait.) Showed the anti-obesity effects in the form of steeping tea [11]. This study aims to determine the potential of anti-obesity effect of ethanol extract of white jasmine (Jasminum sambac (L.) W.Ait.) In vivo in mice induced by high-fat foods.

\section{METHOD AND PROCEDURE}

This research is a laboratory experiment research. This research is on the potential anti-obesity effects of white jasmine ethanol extract (Jasminum sambac (L.) W.Ait.) in vivo in mice induced high-fat foods.

\section{Manufacture of Ethanol Extract}

Jasminum sambac (L.) W.Ait. used were obtained from jasmine plantations in Cirebon regency, West Java. Further determined in Herbarium bandungense of SITH-ITB (Institut Teknologi Bandung). Manufacture of Jasminum sambac (L.) W.Ait. ethanol extract as much as $1.55 \mathrm{~kg}$ by maceration method using ethanol

\section{6\%.Preparation of Animal Experiments}

Animals used in this study were male mice strain Swiss-webster. Prior to testing, mice were used in this study was adapted for 7 days in a cage that is good to adjust to the environment and were fed with normal food and drink enough.

\section{Normal Food Manufacture and Inducers}


Table 1. Composition of normal food and inducers [15]

\begin{tabular}{clcc}
\hline No & \multicolumn{1}{c}{ Materials } & $\begin{array}{c}\text { Normal food } \\
\text { Weight }(\%)\end{array}$ & $\begin{array}{c}\text { Inducers foc } \\
\text { Weight }(\%\end{array}$ \\
\hline 1. & Corn flour & 25 & 25 \\
2. & Fish meal & 16 & 16 \\
3. & Mung bean flour & 14 & 14 \\
4. & Wheat flour & 41 & 13 \\
5. & Vegetable oil & 4 & - \\
6. & Beef tallow & - & 32 \\
& Total & $100 \%$ & $100 \%$ \\
\hline
\end{tabular}

\section{Testing of Anti-obesity Effect of Jasminum} sambac (L.) W.Ait. Extract

A total of 30 male mice strain Swisswebster grouped into six groups each consisting of 5 mice. All groups (except group I was fed normal) induced by high-fat feeding is done for 30 days. After administration of induction which aims to fatten mice, each group has a different weight $>20 \%$ of normal weight (initial weight). Then testing ethanol extract of white jasmine flowers.

Table 2. The treatment group of mice that had been induced by a high-fat diet

\begin{tabular}{|c|c|}
\hline Test Group & Treatment \\
\hline Group I (negative control) & $\begin{array}{l}\text { Given the suspension of Sodium- } \\
\text { CMC solution } 0.5 \%\end{array}$ \\
\hline Group II (positive control) & $\begin{array}{l}\text { Given the suspension of Sodium- } \\
\text { CMC solution } 0.5 \%\end{array}$ \\
\hline Group III (comparison) & $\begin{array}{l}\text { Given a solution of orlistat } 23 \\
\mathrm{mg} / \mathrm{kg} \text { in a suspension of Sodium- } \\
\mathrm{CMC} \text { solution } 0.5 \%\end{array}$ \\
\hline Group IV (test dose 1) & $\begin{array}{l}\text { Given the ethanol extract of } \\
\text { Jasminum sambac (L.) W.Ait.dose } \\
\text { of } 100 \mathrm{mg} / \mathrm{kg} \mathrm{BW} \text { in a suspension } \\
\text { of Sodium-CMC } 0.5 \%\end{array}$ \\
\hline Group V (test dose 2) & $\begin{array}{l}\text { Given the ethanol extract of } \\
\text { Jasminum sambac (L.) W.Ait.dose } \\
\text { of } 300 \mathrm{mg} / \mathrm{kg} \text { BW in a suspension } \\
\text { of Sodium-CMC } 0.5 \%\end{array}$ \\
\hline Group VI(test dose 3) & $\begin{array}{l}\text { Given the ethanol extract of } \\
\text { Jasminum sambac (L.) W.Ait. dose } \\
\text { of } 500 \mathrm{mg} / \mathrm{kg} \mathrm{BW} \text { in a suspension } \\
\text { of Sodium-CMC } 0.5 \%\end{array}$ \\
\hline
\end{tabular}

This treatment is carried out for 2 weeks. For daily body weight, food waste, feces, and urine weight were weighed every 2 times per week. And also analyzed the consistency of feces.

\section{RESULTS}

\section{Ethanol Extracts Manufacture of} Jasminum sambac ( L. ) W.Ait.

The result of determination shows that the materials used in the research potential of anti-obesity effect of this are true Jasminum sambac (L.) W.Ait.

Jasminum sambac (L.) W.Ait. extracted by maceration method using ethanol $96 \%$ at room temperature for $3 \times 24$ hours, the results obtained liquid extract as much as $9.44 \mathrm{~L}$. Extract concentration done by evaporation using a Rotary Evaporator at $40^{\circ} \mathrm{C}$. The viscous extract obtained as much as 82.21 grams with a yield is $5.30 \%$.

\section{Analysis of Test Results During Phase of}

\section{Induction Treatment}

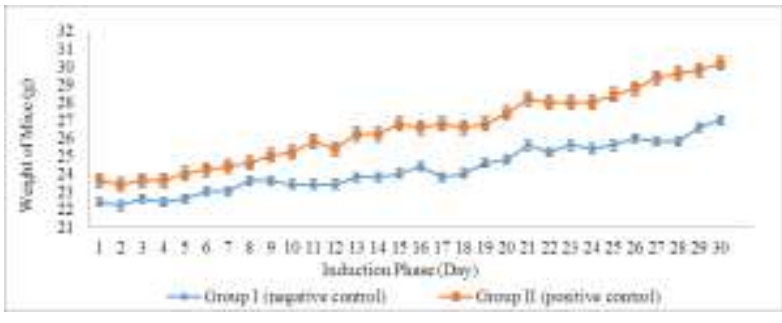

Figure 1. Comparison of body weight of mice (g) between groups I (negative control) and groups II (positive control) until induction phase.

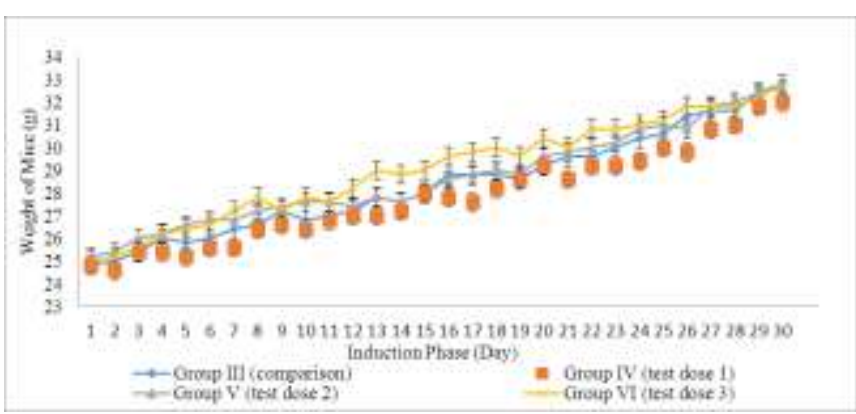


Figure 2. Comparison of body weight of mice (g) between groups III (comparison), groups IV (test dose 1), groups V (test dose 2) and groups VI (test dose 3) until induction phase.

\section{Analysis of Test Results During Phase of Therapy Treatment}

This treatment is carried out for 2 weeks. For daily body weight were weighed every day. Leftovers, weight feces and urine were weighed every 2 times per week. And analyzed the consistency of feces.

\section{Analysis of Daily Weighting}

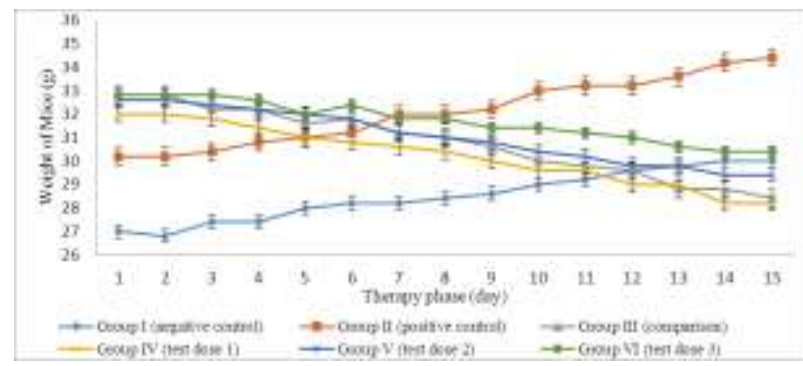

Figure 3. Effect of the Jasminum sambac (1.) W.Ait. ethanol extract on the weight reduction mice $(\mathrm{g})$ between the test groups during the therapy phase.

Based on the result of normality (Shapiro-Wilk) with $p>0,05$ it states that the data distribution of all test groups is normally distributed. On the homogeneity test (Levene test) with $p>0.05$ states that the whole group data varies homogeneously. From result of ANOVA test with $p>0,05$ and $F$ count $>F$ table $(3.892>2.77)$ with significance $p<0.05$ $(\mathrm{p}=0.014)$ stated that all test group there is significant difference.

The result of LSD statistic data from the significant value of comparison between each group stated for induction group more significant than the normal group with $p>0.05$ $(\mathrm{p}=0.057)$ but no significant difference in both groups means that the body weight increased significantly induction group than the normal group. In the comparison group, there was a significant difference with the dose group of $300 \mathrm{mg} / \mathrm{kg} \mathrm{BW}$ and dose of 500 $\mathrm{mg} / \mathrm{kg}$ BW but there was no significant difference with the dose of $100 \mathrm{mg} / \mathrm{kg} \mathrm{BW}$.

Analysis of Food Index, Stool Index, and Urine Index

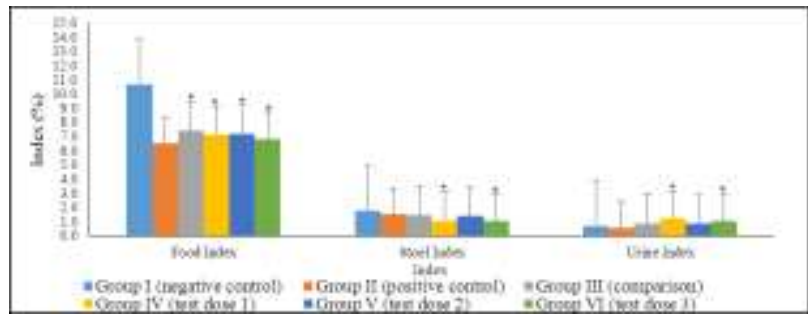

Figure 4. Effect of the Jasminum sambac (1.) W.Ait. ethanol extract in food index, stool index and urine index on the 15th day during the therapy phase. (Sign * indicates a significant difference with group I (negative control) with significance $\mathrm{P}<0.05$ ).

The result of normality test (Shapiro-Wilk) with $p>0,05$ indicates that the data distribution of all test groups is normally distributed. On the homogeneity test (Levene test) with $p>0.05$ states that the whole group data varies homogeneously.

On the 15th day of the food index analysis of ANOVA test results obtained $\mathrm{F}$ count $>\mathrm{F}$ table (28.722> 2.77) with significance $\mathrm{P}$ $<0.05(\mathrm{P}=0.000)$ stated that the whole test group there was a significant difference. Based on LSD test it is known that induction, comparison, dose $100 \mathrm{mg} / \mathrm{kg} \mathrm{BW}$, dose 300 $\mathrm{mg} / \mathrm{kg} \mathrm{BW}$ and dose $500 \mathrm{mg} / \mathrm{kg} \mathrm{BW}$ have a significant difference with the normal group. In the third dose test group showed no 
statistically significant differences with the comparison group.

From the analysis of the fecal index of ANOVA test results obtained $\mathrm{F}$ arithmetic $<\mathrm{F}$ table $(2.383<2.77)$ with significance $\mathrm{P}>0.05$ $(\mathrm{P}=0.080)$ stated that the whole test group there was a meaningless difference. Based on LSD test it is known that dose group 100 $\mathrm{mg} / \mathrm{kg} \mathrm{BW}$ and dose $500 \mathrm{mg} / \mathrm{kg} \mathrm{BW}$ have a significant difference with the normal group. In the third dose test group showed no statistically significant differences with the comparison group.

From the statistical results showed that the three doses showed a significant difference with the normal group, but the value of third dose index of the dose was lower than the normal group. Based on LSD test it is known that dose group $100 \mathrm{mg} / \mathrm{kg} \mathrm{BW}$ and dose 300 $\mathrm{mg} / \mathrm{kg} \mathrm{BW}$ have a significant difference with the normal group. In the dose, $100 \mathrm{mg} / \mathrm{kg} \mathrm{B}$ test group showed a statistically significant difference with the comparison group.

\section{DISCUSSION}

Animals used in this study were male mice Swiss-webster strain with body weight between 20-30 grams of 2-3 months old. Gender of the test animals have been male mice goal is to avoid the influence of hormonal such as estrogen against her condition as in female mice. Because estrogen can affect the body's blood cholesterol test animals which further influence on the test animal obesity [1].
Grouping of animals was carried out at random, so it can be assumed that each group had the same conditions at the start of the experiment. The mice were divided each into six treatment groups for testing anti-obesity effect in mice induced by high-fat foods. Prior to this research beforehand test animals adapted to its environment for one week. The purpose of adaptation to condition or adjusting the test animals with good environmental cage, food, and drinks were given to test animals. After the animal was adapted for 7 days, followed by the induction phase. All groups (except the normal group was fed normal) induced by high-fat feeding is done for 30 days. Giving induction which aims to obese mice, each group has a different weight >20\% of normal weight (initial weight) [15].

From Figure 1 it can be seen that the two groups have significant differences, in the normal group were fed a normal increase in body weight of mice differ significantly with the induction group, while in the induction group were given a high-fat feed so that an increase in body weight for 30 days significantly increased and more compared to the normal group.

From Figure 2 it can be seen that all groups of test animals induced by high-fat feed experienced a significant increase in body weight in the treatment during the induction phase of 30 days. This means that all the test groups were induced high-fat feed successfully induced by an increase in body 
weight of more than $20 \%$ of normal weight (initial weight) so that all the test animals induced by high-fat feeding obese.

From Figure 3 it can be seen that between the normal group and the induction group has significant differences, in the normal group fed normal weight gain of the mouse significantly different from the induction group, whereas in the induction group that fed high fat so that the body weight increase for 30 days increased and more significant than the normal group.

In the therapy phase from day 1 to day 15 , the weight of the body weight is decreased significantly compared to the extract group. Of the 3 doses used that can be seen at a dose of $100 \mathrm{mg} / \mathrm{kg} \mathrm{BW}$ reduction weight of mice is more significant than the dose of $300 \mathrm{mg} / \mathrm{kg}$ $\mathrm{BW}$ and dose $500 \mathrm{mg} / \mathrm{kg} \mathrm{BW}$. While the dose of $300 \mathrm{mg} / \mathrm{kg} \mathrm{BW}$ decreased more significantly than the dose of $500 \mathrm{mg} / \mathrm{kg} \mathrm{BW}$. Thus, the best dose for weight loss of mice was $100 \mathrm{mg} / \mathrm{kg}$ BW compared to $300 \mathrm{mg} / \mathrm{kg}$ BW and $500 \mathrm{mg} / \mathrm{kg} \mathrm{BW}$.

Observations on the index of food consumed were based on the mechanism of action of drugs that can reduce body weight by reducing appetite, decreased appetite when the reduced calorie intake and body weight go down [11]. Figure 4 shows that the normal group has a higher food consumption trend than the induction, comparison, and test groups. And in the comparison group had a higher appetite increase than the test group. This is because the comparisons used are orlistat (dose $23 \mathrm{mg} / \mathrm{kg} \mathrm{BW}$ ) is not an antiobesity drug that works by suppressing appetite mechanism. From statistical data indicate that there is a significant difference between the test group and normal group, so there is a possibility that the test group has the effect of decreasing appetite.

Observations on the feces index are based on the mechanism of action of drugs that can reduce the body weight is a laxative, through nature laxative reduced fat absorption and fat come out with feces thereby inhibiting the accumulation of fat in the adipose tissue resulting in inhibition of the increase in body weight [11]. In the consistency assessment of mouse feces in the therapy, the phase is by using the assessment $0-4$. Where the value 0 means solid/normal, the value of 1 means soft, the value of 2 means fatty soft, the value 3 means the liquid soft and the value 4 means liquid. In the normal group, the consistency of feces solid/normal because in the normal group at the time of therapy phase only given normal food (low fat).

In the induction group, the consistency of the feces is on average soft because at the time of the therapy phase given high-fat diet. In the comparison group, the consistency of feces was the average fatty lump because it was fed a high-fat diet and administered orlistat drug as a comparative drug for testing the anti-obesity effect of white jasmine extract. While for the group of 100, 300 and $500 \mathrm{mg} / \mathrm{kg}$ body consistency of fecal mice the average flabby to fat flabby because given 
high-fat feed and given jasmine white extract at doses 100, 300 and $500 \mathrm{mg} / \mathrm{kg} \mathrm{BB}$.

Observations on the urine index are based on the mechanism of action of drugs that increase urination or are diuresis [11]. Increasing the amount of urine, means increased excretion of various metabolites in the body, including fat metabolites. Increasing the amount of urine will increase the excretion of fat metabolites, which also means increased fat metabolism, thus reducing the risk of obesity [12]. From the statistical results show that the best dose as an antiobesity effect through the mechanism of diuresis is a dose of $100 \mathrm{mg} / \mathrm{kg}$ body weight. This is in line with the weight loss parameter that the dose of $100 \mathrm{mg} / \mathrm{kg} \mathrm{BW}$ is more significant than the dose of $300 \mathrm{mg} / \mathrm{kg}$ and dose $500 \mathrm{mg} / \mathrm{kg}$ BB.

\section{CONCLUSION}

The research result test potential antiobesity effects of ethanol extract of white jasmine (Jasminum sambac (L.) W.Ait.) showed that the best dose that is effective in a statistically significant reduction in body weight that a dose of $100 \mathrm{mg} / \mathrm{kg} \mathrm{BW}$ compared to the dose of $300 \mathrm{mg} / \mathrm{kg} \mathrm{BW}$ and $500 \mathrm{mg} / \mathrm{kg} \mathrm{BW}$.

\section{REFERENCES}

[1] Assaat, L.D. Fraksinasi senyawa aktif minyak kencur (Kaempferia galanga L.) sebagai pelangsing aromaterapi secara in vivo. Institut Pertanian Bogor. Bogor; 2011.
[2] Bruun JM., Helge JW, Richelsen B, Stalknecht D. Diet dan exercise reduce low-grade inflammation and macrophage infiltration in adipose tissue but not in skeletal muscle in severely obese subjects. Am J Physiol Endocrinol Metab. 2006. 290: E961E967.

[3] Dalimartha, Setiawan. Atlas tumbuhan obat indonesia jilid 6. Jakarta: Puspa Swara. 2009.

[4] [Depkes RI] Departemen kesehatan republik indonesia. laporan riset kesehatan dasar. Jakarta : Depkes RI. 2008.

[5] Downey M, JS Stren, Kazaks A. Future and implications of reimbursement for obesity treatment. 2005. http://clevelandclinic.org/health/healthi nfo/2400/2451/.asp? index $=9472$. Diakses 17 Nov 2013.

[6] Elvira. Penanganan psikologik pada obesitas. Cermin dunia kedokteran (CKD). November-Desember. 2007. 34(6):159.

[7] Flier JS, Flier EM. Biology of obesity. Dalam: Fauci AS, Kasper DL, Longo DL., penyunting. Harrison's principles of internal medicine. New York: McGraw Hill. 2008. 17(7):462.

[8] Kalaivani K, Kalaiselvi M, Narmadha R, Rgavendhran P, Arul Raj, Sophia D, Ravi Kumar G, Uma C. In Vivo simulated in vitri model of Jasminum sambac (Linn.) using mammalian liver slice technique. Asian Pasific Journal of Trofical Biomedicine. 2011. S216S219.

[9] Kalaivani K, Kalaiselvi M, Narmadha R, Rgavendhran P, Arul Raj, Sophia D, Ravi Kumar G, Uma C. In vivo and in vitro antitumor activity of Jasminum sambac (Linn,) Ait Oleaceae flowers against dalton's ascites lymphoma induced swiss albino mice. International Journal of Pharmacy and Pharmaceutical Sciences. 2012. 4:144147.

[10] Kunhachan P, Banchonglikitkul C, Kajsongkram T, Khayungarnnawee A, Leelamanit W. Chemical composition, toxicity, and vasodilatation effect of the 
flowers extract of Jasminum sambac (L.) Ait. "G. Duke of Tuscany". Evidence-Based Complementary and Alternative Medicine. 2012. 7 pages.

[11] Lestari NH. Aktivitas antiobesitas rimpang rumput teki (Cyperus rotundus L.), bunga melati (Jasminum sambac (L.)Ait.) dan kombinasinya pada tikus yang diinduksi makanan tinggi lemak. Sekolah Tinggi Farmasi Bandung. Bandung. 2007.

[12] Rahayu,T. Aktivitas Antiobesitas Jati Belanda ( Guazuma ulmifolia L.), Kemuning ( Murraya uaniculata [L.] Jack) dan Kombinasinya Terhadap Tikus Yang Diinduksi Makanan Tinggi Lemak. Sekolah Tinggi Farmasi Bandung. Bandung. 2007.

[13] Rath CC, Devi S, Dash SK, Mishra R. Antibacterial potential assessment of Jasmine essential oil against E. coli. Indian Journal of Pharmaceutical Sciences. 2008. 70(2):238-241.
[14] W.H.O. Expert consultation, "Appropriate body-mass index for Asian populations and its implications for policy and intervention strategies," The Lancet. 2004. 363:157-163.

[15] Yuniarto A, Finn S, Adnyana IK, Elin Y., Anti-obesity effect of the pomegranate leaves ethanol extract (Punicagranatum L) in high-fat diet induced mice. Int $\mathrm{J}$ Pharm Sci. 2014.6(4):626-631.

[16] Zhao HL, Sim JS, Shim SH, Ha YW, Kang SS, Kim YS. Anti-obese and hypolipidemic effects of pltycodin saponins in diet-induced obese rats: evidences for lipase inhibition and calorie intake restriction. Int. J. Obes. (Lond.). 2005. 29:982-990. 